- ACORN Australan college of | JOURNAL OF PERIOPERATIVE NURSING

Volume 33 | Issue 4

Article 3

$11-23-2020$

\title{
From theatre to perioperative: A brief history of early surgical nursing
}

Follow this and additional works at: https://www.journal.acorn.org.au/jpn

Part of the Perioperative, Operating Room and Surgical Nursing Commons

cC) (i)

This work is licensed under a Creative Commons Attribution 4.0 License.

\section{Recommended Citation}

Hamlin, Lois (2020) "From theatre to perioperative: A brief history of early surgical nursing," Journal of Perioperative Nursing: Vol. 33 : Iss. 4 , Article 3.

Available at: https://doi.org/10.26550/2209-1092.1107

https://www.journal.acorn.org.au/jpn/vol33/iss4/3

This Feature is brought to you for free and open access by Journal of Perioperative Nursing. It has been accepted for inclusion in Journal of Perioperative Nursing by an authorized editor of Journal of Perioperative Nursing. 
Author

Dr Lois Hamlin

DNurs, RN, FACN, FACORN

\title{
From theatre to perioperative: A brief history of early surgical nursing
}

\begin{abstract}
Perioperative nursing is believed to be the first specialisation to arise in nursing and tracing its beginnings is an interesting exercise. The scientific advances made during the latter part of the $19^{\text {th }}$ century resulted in increased numbers of patients in hospitals. Though previously shunned by all but the poorest, hospitals now provided an environment that was safer for surgery than a patient's home, and needed skilled nurses as a result. Florence Nightingale established a school of nursing in England teaching 'sanitary nursing' and ensuring probationary nurses knew about antiseptics and disinfectants. Ms Nightingale stated that it was the duty of every nurse on surgical wards to prevent infection, and until the end of the $19^{\text {th }}$ century the nurses who cared for surgical patients in the wards pre- and postoperatively also prepared for and assisted during surgery. However, in $1889^{*}$ the first dedicated operating room nurse was employed in the USA, and thereafter the role of the theatre nurse became entrenched. That role has evolved significantly since then and continues to do so.
\end{abstract}

\section{Introduction}

This paper presents an overview of perioperative nursing from when the specialty began in the latter part of the $19^{\text {th }}$ century until the latter part of the $20^{\text {th }}$ century. Surgical interventions and models of care have changed dramatically during the last several decades, due to the impact of technological innovations, rising costs, increasing demand and an ageing population", and these have impacted on the role of perioperative nurses. However, these impacts are much better documented than those that occurred in the first hundred years or thereabouts and so have not been addressed here. Delving into the past in order to identify the origins of perioperative nursing is no easy task, not least because its history is nebulous, wasn't always recorded or is not accessible, and is sometimes contested $^{\star *}$. The author welcomes feedback from readers with verifiable material offering confirmatory or alternate viewpoints.

\section{The beginnings of perioperative nursing}

It is reasonable to state that perioperative nursing was not a discrete specialty 120 years ago and was still embryonic in the first decade of the $20^{\text {th }}$ century. The beginnings of perioperative nursing arose from caring for surgical patients, as all nurses needed to be trained to prepare for and assist at operations ${ }^{2}$ as well as care for patients before and after operations. This begs the question: when did nurse training commence, and why?

\footnotetext{
* Note (May 2021): This was originally published incorrectly as 1899.

${ }^{* *}$ An early caveat is that this article is not a systematic review and critical analysis on the topic, and is further constrained by the availability of appropriate sources, not all of which have been digitised. This is especially the situation regarding material from the latter half of the $19^{\text {th }}$ century and the first half of $20^{\text {th }}$ century.
} 


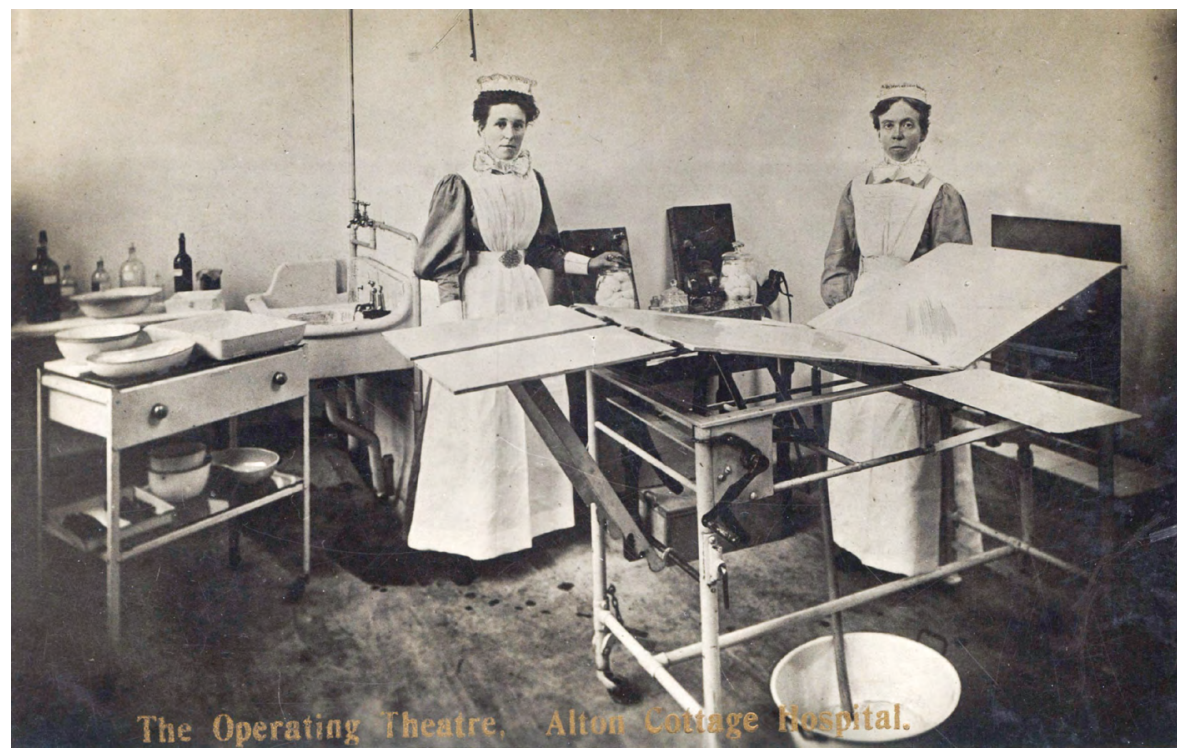

Alton Cottage Hospital operating theatre, Hampshire, United Kingdom (c.1890-1910) Source: US National Library of Medicine (C01045)

There is little evidence of formal training before the mid-1850s other than that associated with religious orders since nursing care was mostly delivered by family members or household servants ${ }^{3}$. However, Florence Nightingale's belief in and implementation of sanitarian principles (hygiene, ventilation, light, nourishing diet and activity) along with advocacy for better resources for hospitals and injured and sick soldiers fascinated the Victorian public. This, along with Nightingale's high personal profile, brought the question of hospital reform and the training of nurses to the forefront of British consciousness in the late $1850 s^{4}$.

The latter half of the $19^{\text {th }}$ century also saw many scientific discoveries. Of note was the work of Pasteur with bacteria and of Lister, a British surgeon, who was developing and using antiseptic solutions ${ }^{5}$. There was also the advent of anaesthesia as well as many other pertinent developments and much social reform occurring ${ }^{3}$. All these developments resulted in the rapid growth of hospitals ${ }^{6}$ as knowledge of asepsis and the need to keep bacteria out of wounds grew. Consequently, the number of surgical cases increased as did the range of surgical interventions, and surgical procedures were undertaken in hospitals whereas previously many had been conducted in patients' homes.

These hospitals needed a skilled nursing workforce. Florence Nightingale established a school of nursing at St Thomas' hospital in 18607 , and in subsequent decades Nightingale-inspired schools were founded in Australia ${ }^{8}$, the United States of America (USA)', Sweden and elsewhere ${ }^{10}$. While Florence Nightingale was initially reluctant to accept 'germ theory', she was staunch in advocating the need for cleanliness, light, fresh air and ventilation; their precepts had underpinned her success during the Crimean war in the early $1850 \mathrm{~s}^{11,12}$, and her teachings focused on the need for nurses to ensure that sanitary conditions were created and maintained at all times. She regarded 'sanitary nursing as essential in surgical as in medical cases, but not to supersede surgical nursing ${ }^{7}$ (p.164). Nightingale also ensured that probationers were taught about antiseptics and disinfectants ${ }^{10}$. Importantly, she stated that, "In surgical wards, one duty of every nurse certainly is prevention ... [of] fever, or hospital gangrene, or pyoemia, or purulent discharge ${ }^{1 \text { (p.165). }}$ Even in the last decade of the $19^{\text {th }}$ century the nurses who cared for their surgical patients in the wards prior to surgery also prepared for and assisted during surgery ${ }^{2,13}$ as well as caring for them after surgery 14 . In some training schools in the USA, a significant amount of a nurse's time during training was spent caring for surgical patients and working in the operating theatre (OT) $)^{15}$.

Operation-specific duties included ensuring that all instruments, sponges, dressings and the water used in an operation were sterilised and, if the operating table was long enough, the nurse should 'admit a hot water bottle at the patient's feet $^{\prime 14}($ (p. 211). In some instances, nurses prepared patients for theatre by dressing them in a clean chemise, nightgown and stockings ${ }^{13}$. Alternatively, they were dressed in lamb's wool or flannel leggings, and a loose lamb's wool jacket although a loose lamb's wool coat-shaped operating gown was also advocated, perhaps for female patients! The nurse also had to prepare herself in the following manner: 'A hot carbolic bath should be taken on the morning of the operation, and perfectly clean clothes put on 14 (p.211).

One of the first examples of a nurse who specialised in working solely in the operating theatre (perhaps even the first) was Caroline Hampton Halsted* $^{*}$ at the Johns Hopkins Hospital in Baltimore in 18896,16. It is likely there were dedicated nurses

\footnotetext{
* Note (May 2021): This was originally published incorrectly as Hampstead.
} 


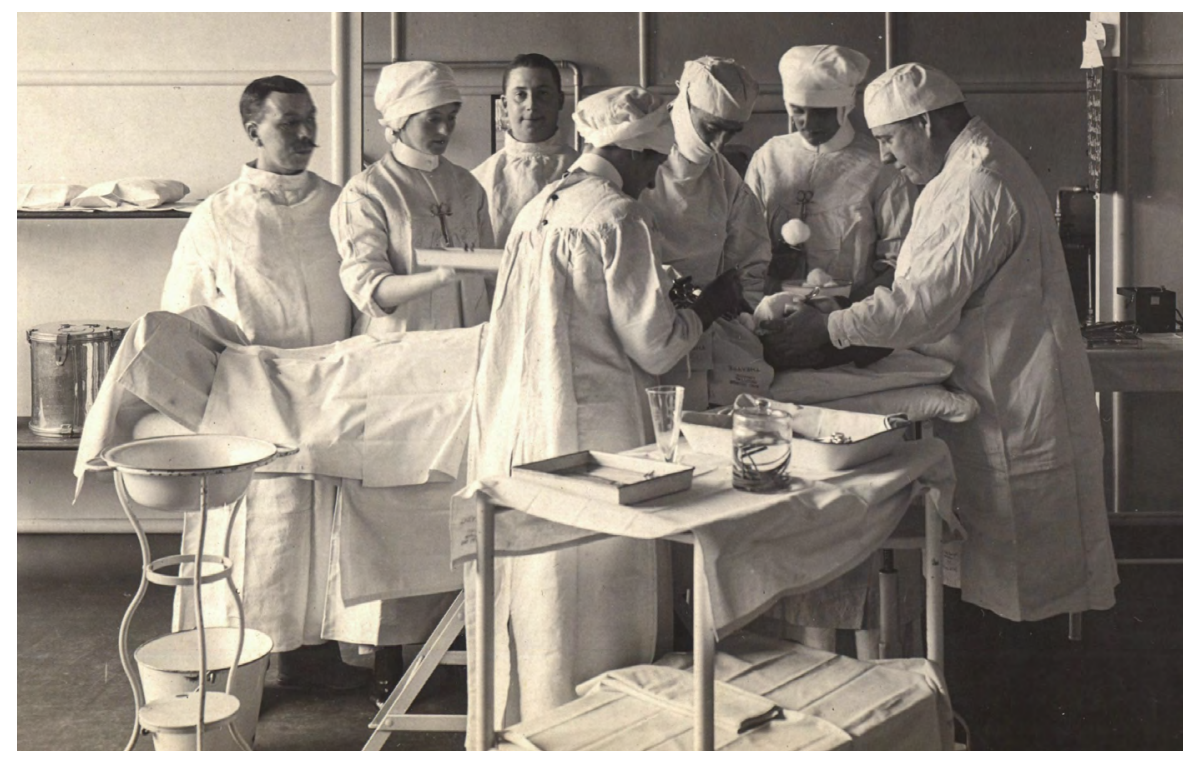

Surgeons and nurses tending to a patient on an operating table at King George Military Hospital, London, England (1915) Source: US National Library of Medicine (D05817)

working in various European hospital OTs at this time, perhaps even earlier, given that surgery was '...far more advanced in Germany, Belgium and France $^{17}$ (p. 513).

Even before the start of the $20^{\text {th }}$ century, nursing textbooks included a chapter on the nurse's role before and during surgery ${ }^{2,13}$ and there was much information published on this topic in The Nursing Record (later The Nursing Record \& Hospital World), the forerunner of the British Journal of Nursing. These publications were not only an educational source regarding the practice of theatre nursing but also informed readers of new developments in operating theatre design and surgical practice, among many other things. In the USA by 1900 the term 'operating room (OR) nurse' had come into general use as a term of respect for nursing's first speciality ${ }^{6}$. However, this was not the case in other parts of the globe; for example the term used in Australia and the United Kingdom (UK) was 'theatre nurse', which persisted for many decades.

Australian hospitals, like many in the UK and the USA prior to and during the early part of the $20^{\text {th }}$ century, developed their own nurse training courses, there being no national curriculum or standardised examinations. However, at that time, all nurses spent time in theatre as part of their training ${ }^{6,18}$ and did so without the benefit of any lectures! Instead, they learnt by watching. In Australia, the Australasian Trained Nurses' Association (ATNA) was formed in $1899^{19}$, the first Australian nursing organisation which was selfgoverning and whose office bearers were 'prominent medical men and matrons of leading hospitals in Sydney's(p.18). ATNA was established to protect the public from ignorant and incompetent nurses, to improve and standardise general nurse training and to promote the professionalisation of trained nurses. For more than ten years the association determined standards of entry, training (including in theatre techniques) and examination, and professional and personal codes of conduct. (Note: in New South Wales (NSW) in 1924, the state took over and introduced the Nurses Registration Act 1924 (NSW), with other states and territories doing likewise shortly thereafter. For example, in the ACT, nursing registration commenced in
1933 and in Western Australia (WA) a couple of years later $^{20}$.)

\section{Evolution of the role}

During this period the role began to evolve; in Australia, Jane Bell, the Lady Superintendent of Nursing at the Royal Melbourne Hospital, appointed a theatre sister in 1912, the hospital's first such appointee ${ }^{21}$. An early edition of the British Journal of Nursing also outlined the nursing staff of a suite of four theatres in a UK hospital. These included a sister in overall charge, an instrument nurse, a sponge nurse and an assistant nurse in each theatre. The role of the assistant nurse was, 'to do whatever she may be told. $22(0.46-47)$. In due course, the sister in charge role eventually became the theatre superintendent in the UK' ${ }^{23}$. During a comparable time period in Australia, student nurses, 'returned to a great deal of solid cleaning' in their fourth year of training when they went to theatres ${ }^{18\left(p_{164)}\right)}$. Here they scrubbed the walls, lights and the floors with lysol following the departure of the surgeon, a task which took four hours. Each theatre had a sister and two student nurses. The role of the sister was to assist the surgeon, although a notable exception was the Royal Prince Alfred Hospital (RPA) in Sydney where some surgeons (but not all) had 'instrument men' until 1932. The role of these 'instrument men' comprised the care and maintenance of instruments and sterilisation of catgut as well as assisting the surgeon. In these latter cases, the sister was the sponge nurse ${ }^{18}$.

Over the course of the $20^{\text {th }}$ century as the nursing curriculum evolved and its theoretical content increased, concepts associated with theatre nursing were introduced and taught. By the middle of the $20^{\text {th }}$ century, a minimum of 40 days practical experience working in OTs was mandated and this was completed 


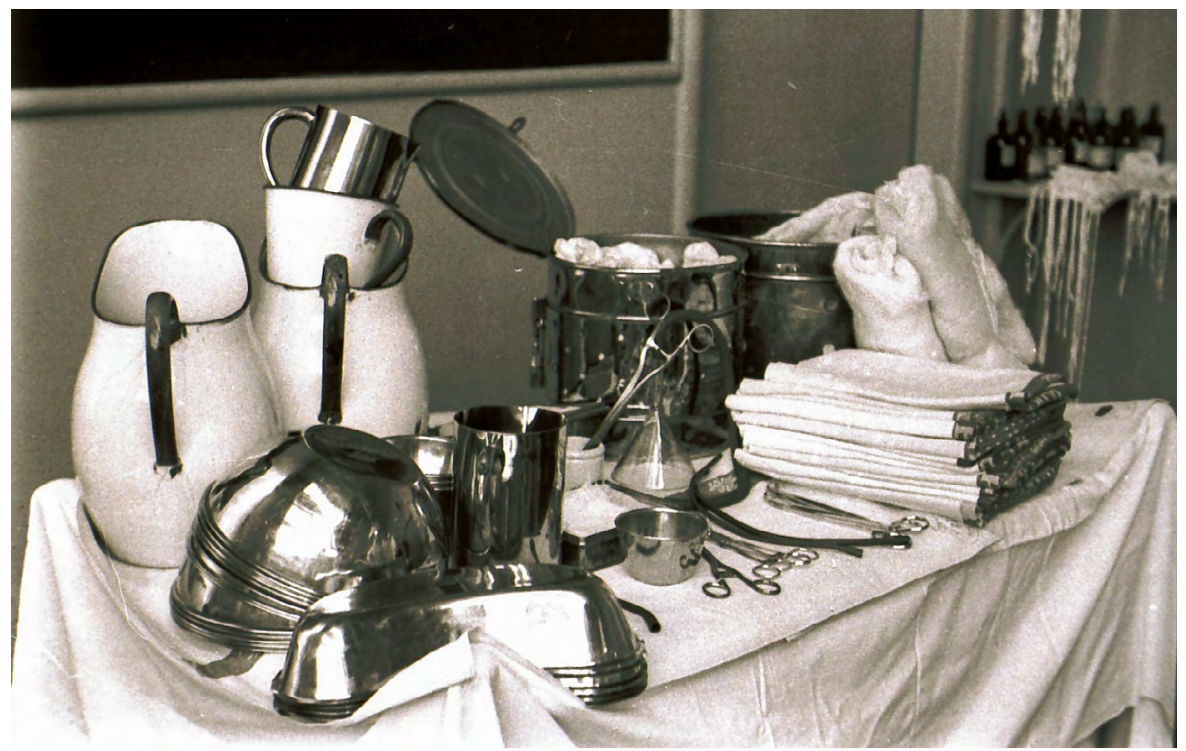

Back table set up (c. 1950s) (c) Victorian Perioperative Nurses Group

during a student nurse's final year ${ }^{8}$. Thereafter, if a student nurse showed an aptitude for working in the OT, the theatre sister in charge would invite them to return on completion of their basic training! Despite these curricular changes, the work of student nurses changed little; they cleaned up the theatres and scrubbed instruments ${ }^{23}$. Even in the 1950s and 1960s nurses' (and sisters') work in theatres at the weekend included winding spools of catgut and sterilising them; working in the clean room, testing, drying, powdering and packing gloves ready for sterilising; counting gauze swabs into packs of five ready for sterilising; polishing instruments and soaking them in 'instrument milk'; and folding linen ${ }^{24}$. Unusually, at Royal North Shore Hospital, Sydney, theatre sisters put student nurses at the instrument table to learn while they were at the sponge table ${ }^{24}$.

An English textbook from the 1960s, Surgery for Nurses ${ }^{25}$, had a 13-page chapter on 'Asepsis and theatre technique' containing information on the following:

- a short section on 'theatre technique' - which, seemingly, was comprised of compelling theatre staff to observe all principles and techniques of asepsis, and included an explanation of theatre attire

- antiseptic and disinfectant solutions

- types of suture materials (including kangaroo catgut!) and needles (all reusable)

- basic information about asepsis and how to undertake various tasks without contaminating sterile items or the surgical team, including the correct method for putting on gloves

- swabs - which, seemingly, were only counted once, before the wound was closed

- prevention of burns and explosions, and the correct use of surgical diathermy

- the requirements and duties of the ward nurse - who brought the patient to and from theatre. It is noted that the ward nurse "is entirely responsible for the patient during transit from the theatre to the ward'25(p.102). The ward nurse was exhorted, above all else, to keep the airway clear, and to that end carried an artificial airway, tongue forceps and a gag. There was no mention of a recovery room and at that time there were very few in evidence in the $\mathrm{UK}^{23,25}$.

In Australia, the NSW College of Nursing offered the first theatre course for registered nurses (RNs), which commenced in $1950^{26}$, while in 1955 the Melbourne-based College of Nursing Australia offered a six-month, full-time theatre management and teaching diploma course which was available to nurses from all states in Australia as well as to nurses from overseas ${ }^{27}$. Hospital-based theatre nursing courses which had their own sister tutor evolved during the latter part of the $20^{\text {th }}$ century and were largely based in teaching hospitals in capital cities. For example, the RPA inaugurated a course on operating theatre techniques in $1964^{26}$, and the Royal North Shore Hospital did likewise shortly thereafter ${ }^{24}$. Following the move of nurse education to the tertiary sector in the latter part of the $20^{\text {th }}$ century these courses followed suit, and postgraduate training is now offered collaboratively with various universities as well as by the Australian College of Nursing (formerly the NSW College of Nursing and the Royal College of Nursing Australia).

The latter part of the $20^{\text {th }}$ century also saw the formation of theatre nursing organisations in Australia and elsewhere globally. In Australia, the NSW Operating Theatre Association was founded in 1957 as was the Theatre Sisters section of the Royal Victorian College of Nursing (now the Victorian Perioperative Nurses Group) ${ }^{27}$. The formation of state-based entities in other jurisdictions followed in due course with the Theatre Sisters Section of the Australian Nursing Federation in Western Australia (which became the Operating Room Nurses 


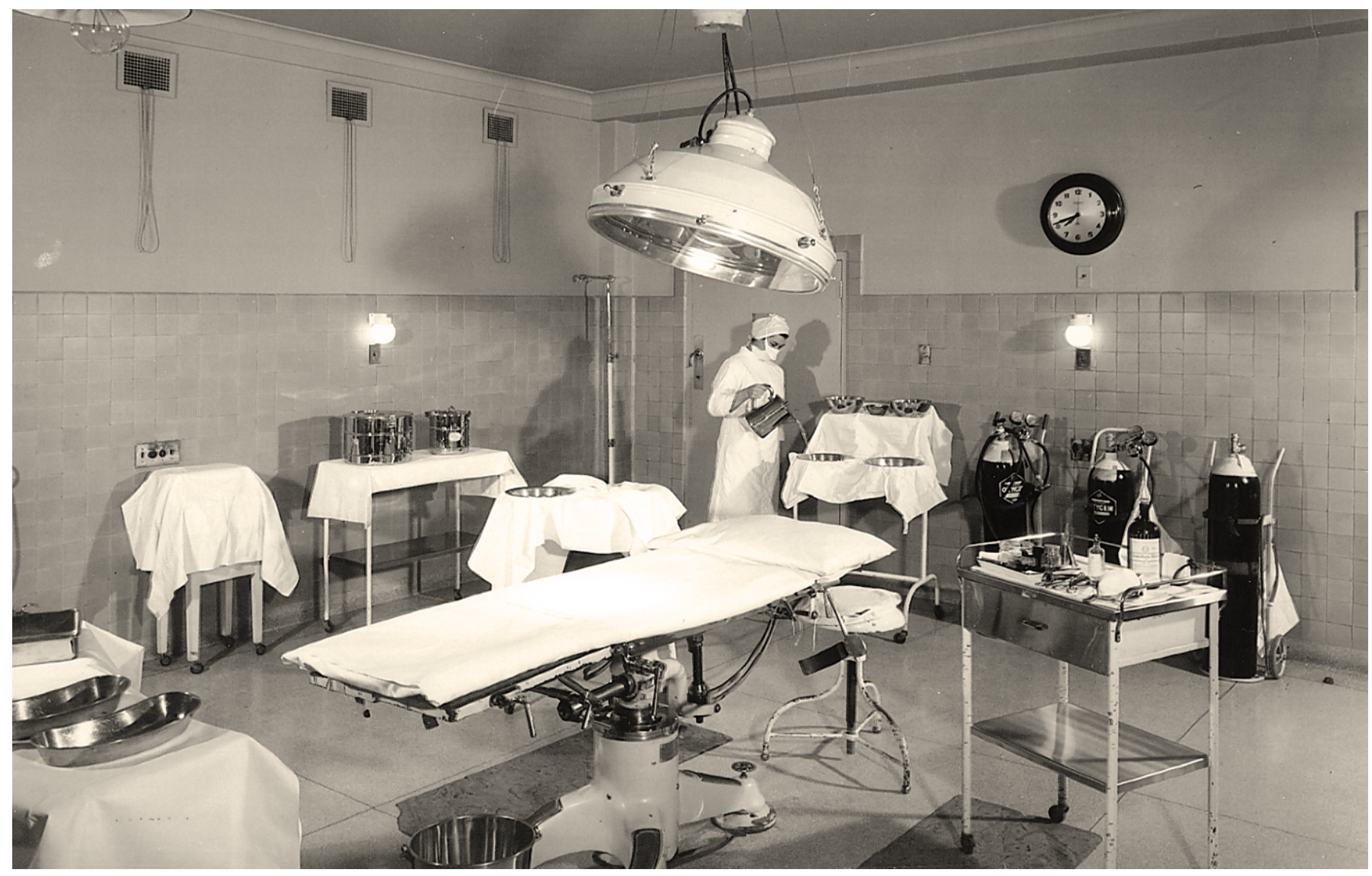

St Georges Hospital major operating theatre, Melbourne, Australia (1953) ๑ Victorian Perioperative Nurses Group

Association Western Australia and is now ACORN WA) in 1966, South Australian Perioperative Nurses Association in 1970, Perioperative Nurses Association of Queensland (now ACORN Queensland) in 1972, Tasmanian Operating Room Nurses (now ACORN Tasmania) in 1973, and the Northern Territory Perioperative Nurses Association, the final group to be formed, in 1990. These groups collaborated in 1977 to form the Australian Confederation of Operating Room Nurses ${ }^{29}$ (now the Australian College of Perioperative Nursing or ACORN). In the USA, the Association of perioperative Registered Nurses (AORN, formerly the Association of Operating Room Nurses) was formed in 1949 and, in the UK, the Association for Perioperative Practice (AfPP, formerly the National Association of Theatre Nurses) formed in $1964^{28}$. All these entities had, and continue to exert, a significant impact on the delivery of perioperative patient care via the development of standards of care, educational endeavours and networking opportunities.

In Australia, at the same time as these changes in education along with the formation of professional nursing organisations were occurring, the role of the 'operating room nurse' was also evolving as was the associated terminology. Scrub and scout nurses became instrument and circulating nurses, while some nurses specialised in particular types of surgery (e.g. working only in highly complex cardiac or neurosurgical arenas) or stages of the patient's journey (e.g. working only in pre-admission, anaesthesia or recovery) reflecting the increasing complexity and nature of surgery and anaesthesia. Additionally, nurses worked in perioperative nursing management positions and as perioperative nurse researchers. Advanced OR roles such as that of nurse practitioner and perioperative nurse surgeon's assistant (PNSA) also came into being. Consequently, around the turn of the century, the term 'perioperative' was adopted, representing the care of patients not only during surgery but across all stages - preoperative, intra-operative and post-operative ${ }^{30}$.

\section{References}

1. Rapley L, Hamlin L. Evolving models of care. In Hamlin L, Davies M, Richardson-Tench $M$, Sutherland-Fraser S (eds). Perioperative Nursing: An Introduction. Chatswood, NSW: Elsevier; 2016, 358-382.

2. Nightingale $\mathrm{K}$. The past as prologue to the future. Br J Perioper Nurs 2000;10(7):354-363.

3. Dingwall R, Rafferty AM, Webster C. An Introduction to the Social History of Nursing. London: Routledge; 1988. 
4. Nelson S. The Nightingale imperative. In S Nelson, AM Rafferty (eds). Notes on Nightingale: The Influence and Legacy of a Nursing Icon. Ithaca, NY: Cornell University ILR Press; 2010, 9-27.

5. Ellis $\mathrm{H}$. The Cambridge Illustrated History of Surgery. 2nd ed. Cambridge: Cambridge University Press; 2009.

6. Clemons B. Diploma schools; the operating room, nursing's first specialty. RN 1973;36(2):OR1-9.

7. Nightingale F. Notes on Nursing: What it is and what it is not. New York: Appleton \& Co; 1860. Available from: www.fulltextarchive. com/pdfs/Notes-on-Nursing.pdf.

8. Russell L. From Nightingale to Now: Nurse Education in Australia. Sydney: W.B. Saunders/Bailliere Tindall;1990.

9. Whelan, J. American nursing: An introduction to the past [Internet]. Philadelphia: University of Pennsylvania School of Nursing; n.d. (cited 2020 July 22). Available from www.nursing.upenn.edu/ nhhc/american-nursing-an-introduction-tothe-past.

10. McDonald L. Florence Nightingale: The Nightingale School: Collected Works of Florence Nightingale, Volume 12. Waterloo, ON: Wilfrid Laurier University Press; 2009.

11. Ellis H. Florence Nightingale: Creator of modern nursing and public health pioneer. J Perioper Pract 2008;18(9):145-146.

12. Schmalbach CE. Patient safety/quality improvement (PS/QI): Florence Nightingale prevails. Otolaryngol Head Neck Surg 2015;152 (5):771-773.
13. St John's Hospital training school. The Nursing Sister: A Manual for Candidates and Novices of Hospital Communities. Springfield, Ill: St John's Hospital Training School; 1899

14. The Matron's Council. A practical demonstration concerning the nursing of operations on the intestinal canal. The Nursing Record \& Hospital World 1896;16:210-212 [Internet]. Available from: rcnarchive.rcn.org.uk/data/ VOLUME016-1896/page210-volume1614thmarch1896.pdf.

15. Clemens B. Rules for OR nursing, 1899. RN 1973;36(2):OR 9.

16. Ellis H. Surgical gloves. J Perioper Pract 2010;20 (6):219-220.

17. Nursing on the continent. Br J Nurs 1914;52:513-514. Available from rcnarchive. rcn.org.uk/data/VOLUME052-1914/page513volume52-06_thjune1914.pdf.

18. Armstrong DM. The First Fifty Years: A History of Nursing at the Royal Prince Alfred Hospital, Sydney from 1882 to 1932. Sydney: Royal Prince Alfred Hospital Graduate Nurses' Association; 1965.

19. Strachan G. Labour of Love: The History of the Nurses' Association of Queensland, 1860-1950. Sydney: Allen \& Unwin; 1996.

20. Crisp J, Douglas C, Rebeiro G (eds). Potter \& Perry's Fundamentals of Nursing, $4^{\text {th }}$ ANZ ed. Sydney: Mosby; 2012.

21. The Royal Melbourne Hospital (RMH). History of the city campus [Internet]. Melbourne: RMH; n.d. (cited 2020 August 18). Available from: www.thermh.org.au/about/ about-rmh/our-history/history-city-campus.
22. Morison R. The instrument nurse. Br J Nurs 1912;48:46-47. Available from: rcnarchive. rcn.org.uk/data/VOLUME048-1912/page0 48volume48-20_hjanuary1912.pdf.

23. Ellis H. 'The Sister' in the early days of the NHS. J Perioper Pract 2016;26(4):50-52.

24. Rice M. The Close of an Era: A History of Nursing at the Royal North Shore Hospital, 1887-1987. St Leonards, NSW: Royal North Shore Hospital Graduate Nurses' Association; 1988.

25. Moroney J. Surgery for Nurses. $11^{\text {th }}$ ed. Edinburgh: Churchill Livingstone; 1967.

26. Croll Wilson H. The Second Fifty Years: A History of Nursing at the Royal Prince Alfred Hospital, Sydney from 1932-1982. St Ives, NSW: Braxus Press; 2000.

27. Williams CR. Unmasked: A history of the Victorian Perioperative Nurses Group. East Melbourne: Victorian Perioperative Nurses Group (ANF Vic); 2010.

28. Cox N. History of the NATN: 40 years and counting. Br J Perioper Nurs 2005:15(5):197205.

29. Cornell J. The History and Activities of the New South Wales Operating Theatre Association Inc. 1957-2007 Celebrating 50 years. Burwood, NSW: New South Wales Operating Theatre Association Inc.; 2007.

30. Sutherland-Fraser S, Osborne S, Bryant K. Perioperative nursing. In Hamlin L, Davies M, Richardson-Tench M, SutherlandFraser S (eds.). Perioperative Nursing: An Introduction. Chatswood, NSW: Elsevier; 2016, $1-29$. 